\title{
On Rearing the Hydroid Zanclea implexa (Alder) and its Medusa Zanclea gemmosa McCrady, with a Review of the Genus Zanclea.
}

\author{
By \\ F. S. Russell, \\ Naturalist at the Plymouth Laboratory. \\ and \\ W. J. Rees, \\ Research Assistant at the Plymouth Laboratory.
}

With 12 Figures in the Text.

Descriptions of the hydroid Zanclea implexa (Alder) in British waters have been given by the following authors, Alder (1857, as Tubularia implexa and Coryne pelagica), Allman (1859, as Coryne Briareus), Strethill Wright (1859) and Alder (1862 as Coryne implexa), Allman (1864 as Zanclea implexa and 1872 as Gemmaria implexa) and Hincks (1872, as Zanclea (Gemmaria) implexa). All these descriptions have been based upon full grown colonies in which the hydranths had a perisarc on the hydrocaulus.

We have recently had the opportunity of following through the complete development of a colony of Zanclea and have reared the medusæ to an adult stage. During their course of development both the hydroid and medusa undergo changes which have systematic importance. For this reason it is worth giving an account of our observations in some detail.

\section{The HydroId.}

On February 3rd, 1936, a small piece of the basal stem of a colony of Eunicella verrucosa dredged from the Eddystone grounds was placed in a bowl of pure sea water. This had on it a small colony of an encrusting polyzoan. On February 6 th there appeared growing out from this colony minute columnar stalks, which four days later developed at their apices five small protuberances (Fig. 1, A). These outgrowths grew into short capitate tentacles and at the same time a few scattered tentacles were developing from the sides of the body so that by February 11th the hydroid had assumed the appearance shown in Figure 1,B. This hydroid was very minute and extensile, and when fully extended measured about $1.5 \mathrm{~mm}$. in length. The hydroid appeared to spring from a naked stolon 
with no visible perisarc and no trace of a hydrocaulus. By the 17th the whole colony had died down, but it started to grow up again on the 19th, and on February 20th had developed to the stage last mentioned. By the 24th the hydranths had apical whorls of five tentacles and about fifteen tentacles irregularly distributed over the body. All the tentacles were capitate and the knobs of the apical tentacles slightly larger than those of the others. A creeping stolon with developing perisarc was now clearly visible in places. On February 28th some of the hydranths had six tentacles in the apical whorl, but the majority still had five. There was still no visible perisarc on the hydrocaulus. On March 4 th there were about 30 polyps, all confined to the polyzoan and the proportions of those with 6 or 5 apical tentacles was about 1 to 2 . There were still about 15 tentacles on the body. By March 15th it was evident that the hydroid was a species of Zanclea ; the number of tentacles now varied from 20 to 26 in all, and the hydranths were about $3.5 \mathrm{~mm}$. in length when fully extended (Fig. 2). It was noted that it " differs from Zanclea implexa by its smaller size, fewer tentacles, and absence of perisarc on the hydrocaulus."

By the 23rd the polyps had grown considerably in size; they were now very tall and extremely extensile, reaching a length of nearly $10 \mathrm{~mm}$. (See Fig. 3). There were about 40 tentacles in all. At the same time many had developed short ringed perisare on the hydrocaulus. The hydranth was almost perfectly cylindrical in shape, only broadening slightly in the region from which the apical whorl of 6 tentacles sprang. The endodermal core of the hydranth was red and the proboscis white. The colony had now been growing for six weeks, when on March 24th very small polyps were noticed springing up amongst the others. In these the tentacles were reduced in size and number; they were short and there were only 10 to 12 tentacles on the hydranth body some of which were mere knobs. Below the tentacled region of the hydranth small medusa buds were developing. An individual drawn on March 26th had four large buds, approximately radially disposed, each with a smaller bud on its supporting pedicel. A drawing of a portion of the colony as it appeared on March 28th is given in Figure 3 .

On March 30th some of these medusiferous polyps were nearly as long as the original vegetative polyps, but the tentacles were stunted and reduced in number. There were no tentacles below the medusa buds. On April 1st the first medusæ were liberated and identifiable as Zanclea implexa (after Allman, 1872). For many weeks after this medusæ were being produced and the medusiferous polyps showed considerable variation. In some the medusa buds were arranged in a fairly compact whorl; in others they were much more scattered, though always below the tentacles. In some the tentacular portion of the hydranth was much reduced so 


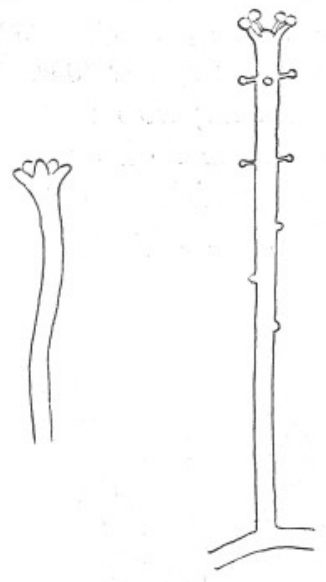

A

Fig. 1.

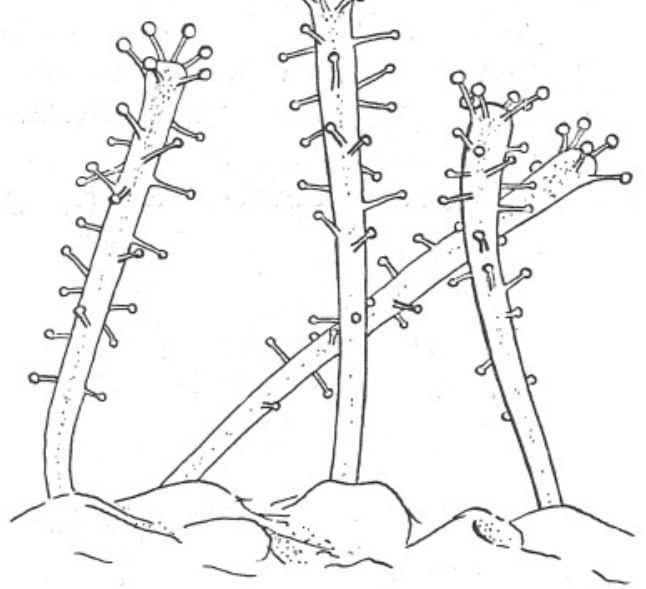

FIg. 2.

FIG. 1.-A. First appearance of developing hydranth of Zanclea implexa ; Plymouth, 10.ii.36.

B. Early stage of hydranth of Zanclea implexa, $1.25 \mathrm{~mm}$. in height; Plymouth, 11. ii.36. Del. F.S.R.

FIG. 2.-Portion of young colony of Zanclea implexa, hydranths $3 \mathrm{~mm}$. in height; Plymouth, 15.iii.36. Del. F.S.R.

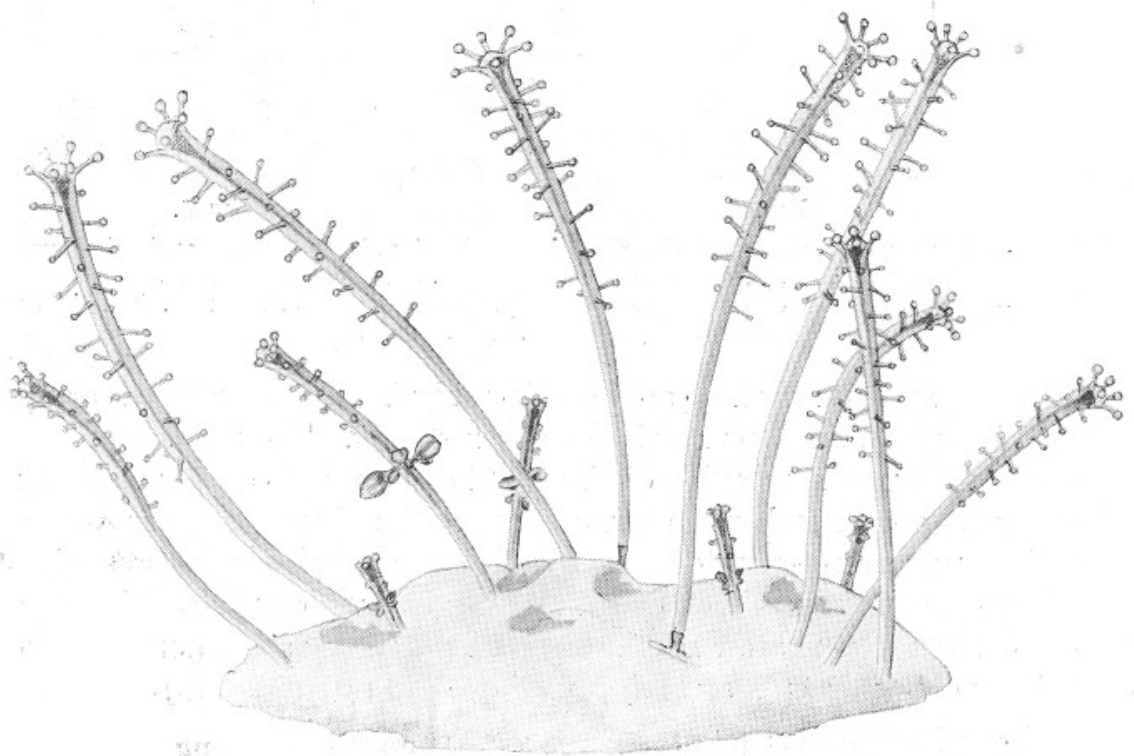

Fig. 3.-Portion of colony of Zanclea implexa, height of longest polyp, ca. $10 \mathrm{~mm}$; Plymouth, 28.iii.36. Del. F.S.R. 
that there were only about 8 tentacles and the basal portion of the column was thicker ; in extreme cases the polyps were reduced to mere blastostyles (see Fig. 4). On April 20th some of the medusiferous polyps, now $10 \mathrm{~mm}$. long when fully extended, appeared to be regenerating into normal vegetative polyps; those which had liberated all their medusæ had tentacles increasing in number and size, and others on which there were still medusa buds had tentacles developing below the buds (Fig. 4). The

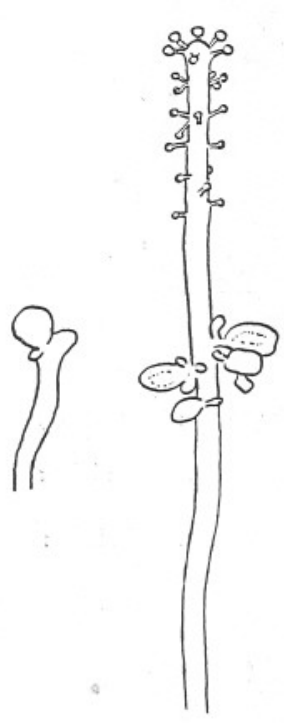

A

B

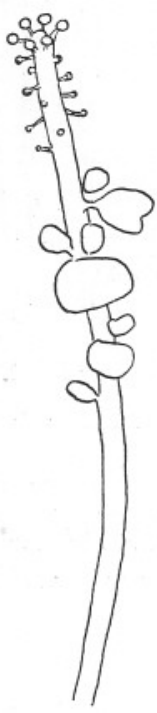

C

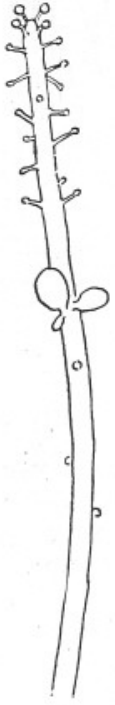

D

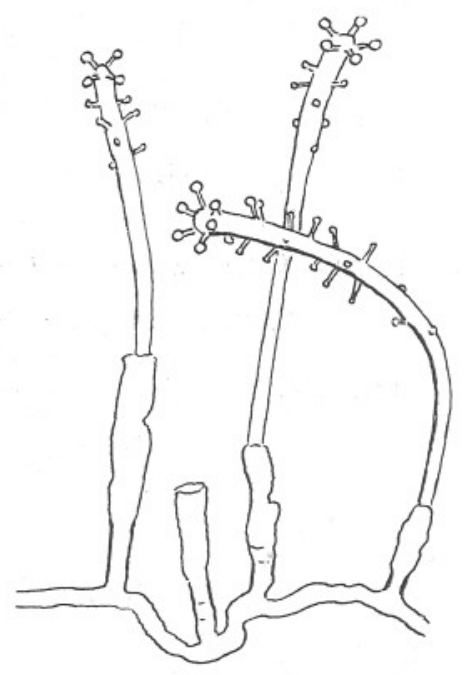

FIG 5.

Fig. 4.- Showing different types of medusa bud formation, in colony of Zanclea implexa, Plymouth. A, C, 4.iv.36; B, 30.iii.36; D, 20.iv.36. Del. F.S.R.

Fia. 5.-Portion of old colony of Zanclea implexa regenerating, $2.5 \mathrm{~mm}$. in height; Plymouth, 10.vii.36. Del. F.S.R.

whole colony had now increased considerably in size and was spreading over the substratum around the Polyzoan colony. The perisarc on the hydrocaulus was now quite distinct. The colony lived on producing medusæ in great numbers, but apart from noting that the colony tended to die down and regenerate in the middle of May little further attention was given to it for a time beyond keeping it supplied with food. The development of perisarc was still proceeding strongly and measurements of the hydrocaulus on May 30th gave the following results.

$\begin{array}{llllll}\text { Length of perisarc in mm. } \quad .0 .4 & 0.7 & 0.45 & 0.5 & 0.6\end{array}$

$\begin{array}{llllll}\text { Width of perisarc in mm. } & 0.17 & 0.19 & 0.14 & 0.16 & 0.15\end{array}$

One individual had a hydrocaulus with perisarc $1 \mathrm{~mm}$. long. 
The production of medusæ continued throughout June. On July 7th after much of the colony had died down new small polyps were developing in the old perisarc tubes, so that they now appeared as in some of the earlier figures (Fig. 5) but with pronounced perisare on the hydrocaulus.

The colony, which had been kept in a beaker in which the water was agitated since February 13th, was still alive in October.

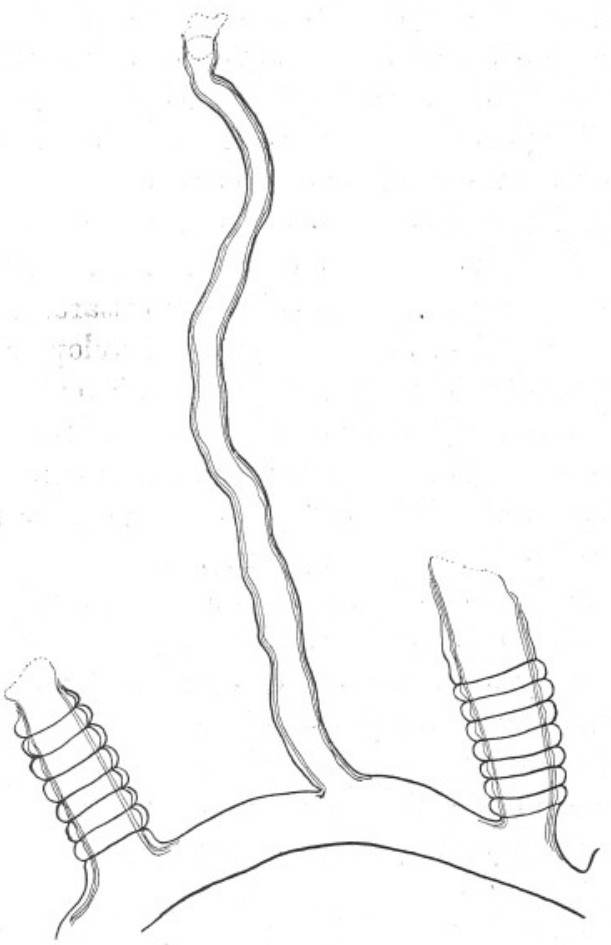

FIg. 6 .

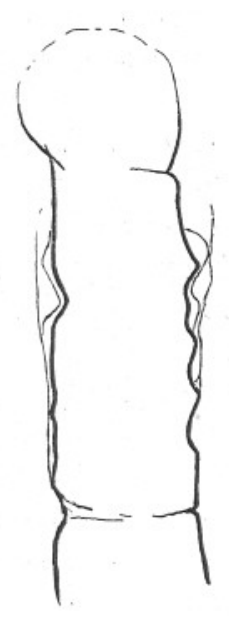

Fig. 7.

FIa. 6.-Portion of perisare of old colony of Zanclea implexa, showing annulation at base of hydrocaulus; Plymouth. Del. W.J.R.

Fig. 7.-Perisarc of hydrocaulus of regenerating hydranth of Zanclea implexa, showing new perisare forming inside old perisare membrane; Plymouth, 12.vii.36. Del. F.S.R.

The hydroid had the three types of nematocysts described by Brückner (1914), namely large and small oval nematocysts, and large elongated beanshaped nematocysts. These latter were situated in the hypostome region.

Measurements of the nematocysts gave the following dimensions :

Small oval

Large oval

Large elongated

$\begin{array}{cc}\text { Average length. } & \text { Average breadth. } \\ 0.007 \mathrm{~mm} . & 0.006 \mathrm{~mm} . \\ 0.013,, & 0.012,, \\ 0.021, \text { * } & 0.008,,\end{array}$

Average length. Average breadth.

Range, 0.020-0.024. 
The perisarc. In the earliest stages there is no visible perisarc. All perisarc must begin as a thin transparent membrane which gradually becomes thickened and visible as a horn-coloured layer. In older individuals the perisarc was well developed both on the hydrorhiza and on the hydrocaulus. The hydrocaulus which grows off approximately at right angles to the hydrorhiza is sometimes strongly ringed at its base (Fig. 6). Above the annulation the hydrocaulus continues as a simple tube often irregularly corrugated and st its upper end the perisarc becomes membranous and transparent as this region is the last to develop. Several authors (see page 119) have remarked on the appearance of an outer periderm separated from the main perisarc. The development of this outer sheath is probably as follows. During the course of the growth of a colony, the polyps frequently die down. A perisarc skeleton is thus left having at its upper end the thin membranous mouth of developing perisarc. A new polyp now grows up within the tube, and as it grows develops a new perisarc. This grows up beyond the old tube, becoming thickened at its lower end. This thickened region thus comes to lie within the upper membranous perisarc of the old tube. In this way the appearance of an outer periderm is produced, which is in reality the last perisarc to be developed by the old polyp before it died down (Fig. 7).

The fact that this colony first appeared in association with a polyzoan led to the supposition that other colonies of Zanclea might be found by obtaining polyzoa. Accordingly a small piece of encrusting polyzoan, Cellepora avicularis Hincks, * dredged near Stoke Point on March 17th was placed in a finger bowl. On March 20th a colony of Zanclea was found to be developing, and its course of development differed somewhat from that just described. It had evidently already passed through its vegetative stage.

The polyps first appeared as short knobbed projections of a pink colour, on the surface of the polyzoan. On development each polyp had an apical whorl of six tentacles, and a few scattered tentacles on the body (Fig. 8, A). After three days they were about $0.5 \mathrm{~mm}$. in height (Fig. 8, C). On March 27th the first medusa buds appeared in a whorl below the tentacles, which now numbered 15 to 20 . No perisarc was visible on any polyp. As the medusa buds grew, the upper tentacled portion of the hydranth became gradually reduced, in some the tentacles were absorbed and the body of the hydranth above the medusa buds became shorter and thinner until the hydranth was reduced to a mere blastostyle (Figs. 8, E G and Fig. 10). The first medusæ, 10 in number, were liberated on April 3rd and 20 to 30 medusæ continued to be liberated daily until the 20 th of the month. Shortly after the first medusæ appeared

* We are indebted to Miss A. Bs Hastings of the British Museum (Natural History) for the identification of this polyzoan. 

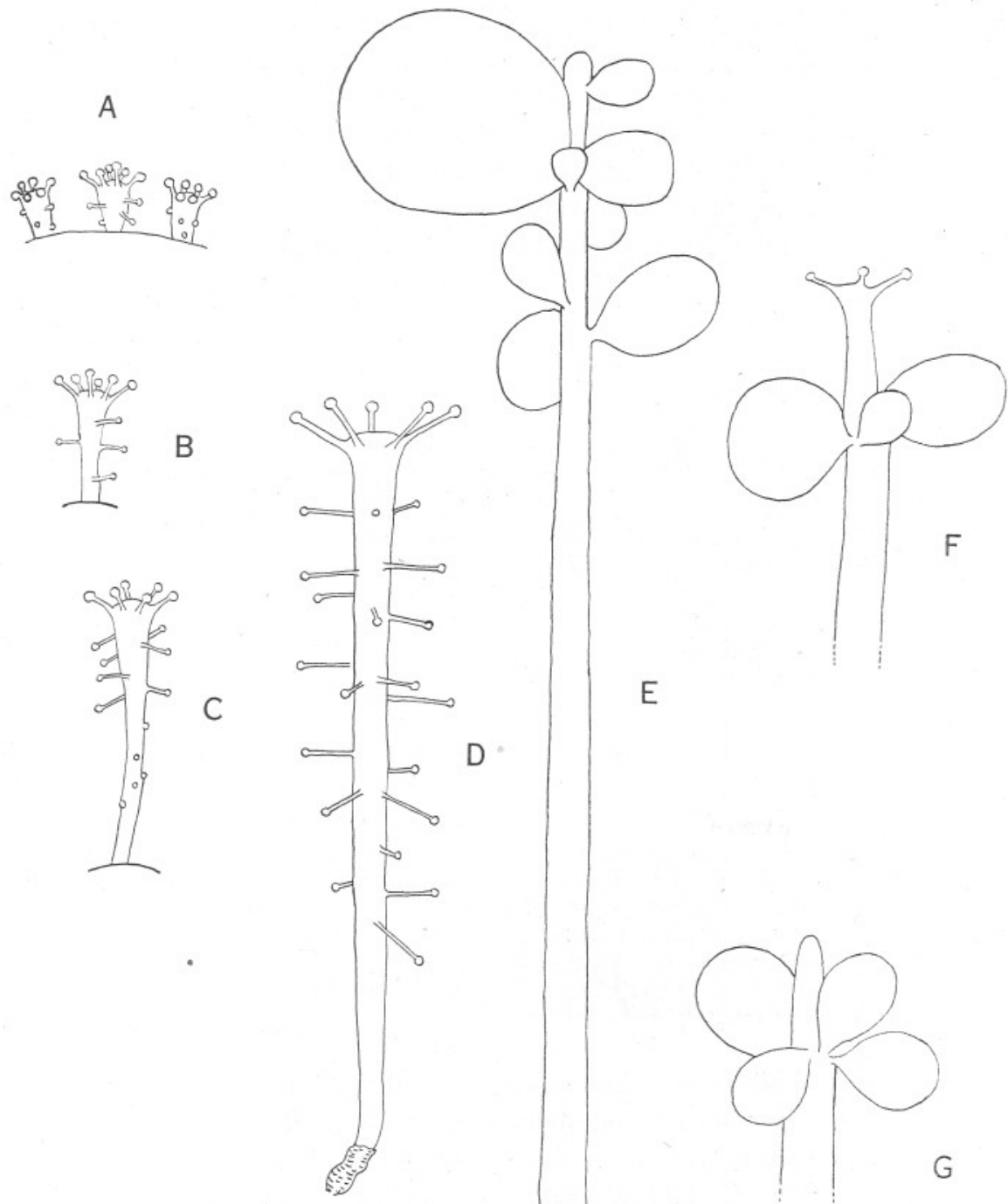

E

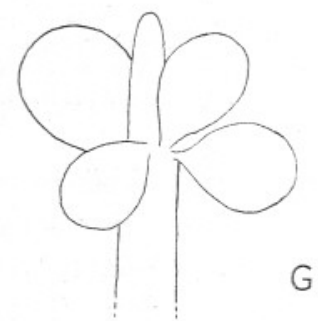

FIG. 8.-A, B, C, D. Various stages of development of the vegetative hydranths of the second colony of Zanclea implexa, Plymouth.

A, first appearance of the hydranths, 20.iii.36; B, a single hydranth two days later, 22.iii.36; C, a single hydranth, 23.iii.36; D, a fully developed hydranth with developing perisare, 26.vi.36.

E, F, and G, various types of medusa bud formation, 17.iv.36. Del. W.J.R. 
the blastostyle stems elongated considerably and many polyps reached a length of $2 \mathrm{~mm}$. (Fig. 9). At first the medusa buds developed more or less in a whorl around the stem, but later two or even three whorls were developed (Fig. 8, E). The majority of the medusa buds had a very short stalk and younger buds rarely developed from this stalk. On the final liberation of their medusæ the blastostyles seemed to disappear overnight and by April 22nd the majority had died down. Two or three days after the disappearance of a blastostyle a very short hydranth developed in its place which developed medusa buds two days later. By April 27th

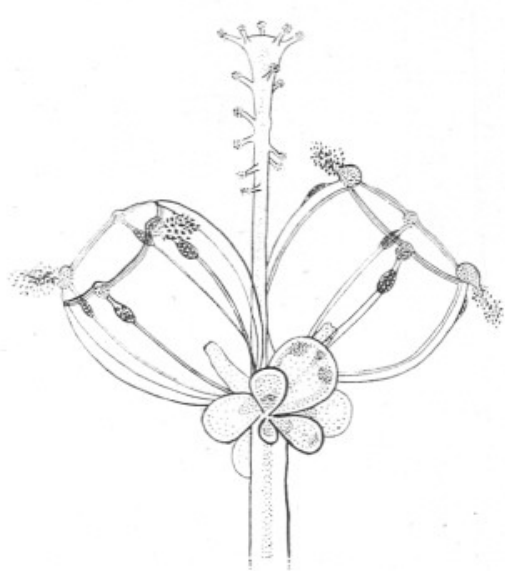

FIg. 9.

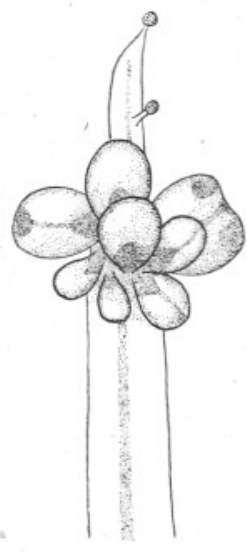

A

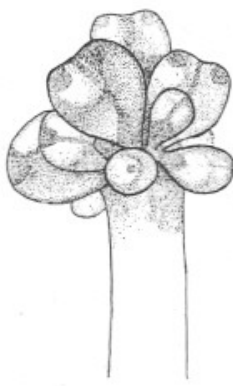

B

FIG. 10.

FIG. 9.-Portion of a single hydranth of second colony of Zanclea implexa $2.4 \mathrm{~mm}$. in height, showing medusa buds and a slight reduction of the upper portion of the hydranth; Plymouth, 3.iv.36. Del. W.J.R.

FIG. 10.-A, Hydranth of second colony of Zanclea implexa with medusa buds almost completely reduced to a blastostyle; Plymouth, 27.iii.36.

B, Hydranth of second colony of Zanclea implexa completely reduced to a blastostyle ; Plymouth, 27.iii.36. Del. W.J.R.

all the original blastostyles had died down and the new set of polyps were differentiated into longer and shorter individuals. The shorter polyps, $0.4 \mathrm{~mm}$. in height, were more numerous and developed medusa buds; the longer polyps, $1 \mathrm{~mm}$. in height, were sterile. On April 30th all the reproductive polyps had increased in length and were similar in appearance to the original series already described. The vegetative polyps had now grown to a length of $1.8 \mathrm{~mm}$. By May 5th all the vegetative polyps also produced and liberated medusæ for a few days, but never became reduced to simple blastostyles. More new polyps were observed growing up on May 8th; these produced two whorls of medusa buds and were only slightly reduced from the vegetative type on the 10 th. By this time other polyps growing up since the 8 th were only slightly longer than the original 
polyps and developed medusa buds by May 15th; all these latter were completely reduced to blastostyles by May 30th, and new shorter polyps were growing up. This cycle was repeated three times during the month of June. Until June 25th the colony had been kept in a finger bowl in still water and there had been no visible perisarc on any polyp. It was then transferred to a beaker in which the water was agitated and after about a week a thin perisarc was seen to be developing round the bases of the polyps (Fig. 8, D.).

It is to be noted that this colony differed slightly from the colony first described in that the hydranths were shorter and there was a much greater tendency to reduction to a complete blastostyle. A section of the polyzoan colony showed the stolon penetrating deeply into the colony.

The association of this hydroid with a polyzoan is of interest and it appears to be a very frequent habit*. Hastings (1930 and 1932) has brought together observations of such associations and it is of interest to reproduce here a remark made by Hargitt (1908). He records that the hydroid may be found at Woods Hole on a variety of objects such as shells of Mytilus and Pecten, Serpulid tubes, pebbles, water-logged wood and floating Sargassum, but adds "In one particular, however, there has been an interesting uniformity in every case which has come to my notice, namely, the colonies are invariably associated with encrusting polyzoa, usually Schizoporella or Membranipora." It would appear that polyzoa may be one of the normal settling grounds for the larval stages of the hydroid, but that in many instances as the colony grows older the stolon creeps away onto the surrounding substratum. Stechow (1911) records it on the foot of a Holothurian.

\section{The Medusa.}

When first liberated the medusæ agreed closely in general appearance with Allman's figure (1872, Plate VII, Fig. 3). The umbrella was bellshaped, 0.6 to $0.7 \mathrm{~mm}$. in height and nearly of the same width. The jelly was uniformly thin. The margin of the umbrella was somewhat square. The four perradial exumbrella nematocyst chambers extended over the surface of the exumbrella for slightly less or more than a third of its height and were connected with the tentacular and non-tentacular bulbs by a narrow channel. The numbers of nematocysts varied considerably from 4 to 17 , generally 10 to 12 , in the dilated portion, to 0 to 4 in the channel itself. These nematocysts were generally more numerous in the chambers on the tentacular radii than in those on the non-tentacular radii. The stomach was cylindrical and did not exceed in length half the height of the umbrella cavity. The mouth was simple and tubular, and beset with nematocysts up to about 15 in number. The four radial canals and

* Nine more colonies developed on Polyzoa dredged off Plymouth (Oct. 1936). 
ring-canal were narrow, and a few large nematocysts, probably from the exumbrella sacs, were occasionally to be seen in the circular canal. There were two tentacles, each having up to 50 stalked capsules on their abaxial surfaces; these capsules were $0.018-0.02 \mathrm{~mm}$. long by 0.013 broad and they contained 2 to 5 nematocysts, usually 3 . They had vibratile cirri which gave them a characteristic trembling movement.* The elongated tentacular bulbs, and the non-tentacular bulbs were filled with nematocysts. Medusæ were occasionally liberated with no tentacles or with two tentacles greatly reduced and having only a few stalked capsules. The tentacle bulbs, non-tentacular bulbs and stomach were pale pink or yellowish in colour (Fig. 11).

At a height of about $0.8 \mathrm{~mm}$. the gonads were clearly visible as interradial swellings, and there was now more pale yellow than pink in the

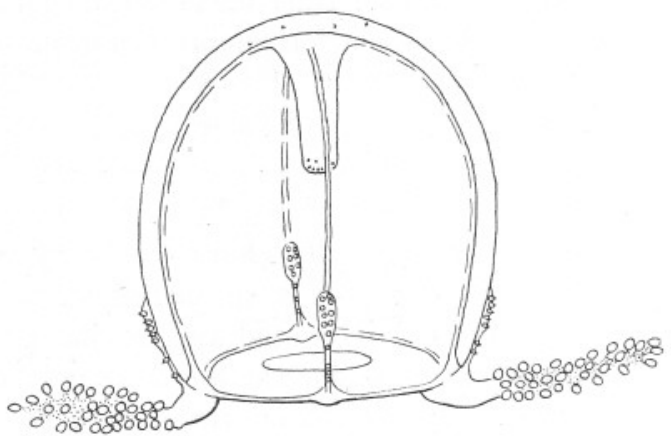

Fig. 11.-Newly liberated medusa of Zanclea implexa, 0.68 mm. in height; Plymouth, l.iv.36. Del. F.S.R.

tentacle bulbs. In some specimens the stomach extended about threequarters of the length of the subumbrella cavity. It is to be noted that there was a tendency for the medusæ liberated from the second colony described above to have slightly longer stomachs and more elongated exumbrella nematocyst channels. At $0.8 \mathrm{~mm}$. the number of stalked capsules on the tentacles had increased, 86 being counted on one tentacle. In specimens about $0.9 \mathrm{~mm}$. in height the gonads were further developed and a bright carmine diffuse spot appeared in the upper half of each tentacle bulb. In some the exumbrella nematocyst chambers had lengthened and become less sac-like, extending half-way up the exumbrella surface. Slight linear swellings were appearing in the middle region of each radial canal. At the same time minute opaque dots were visible on the umbrella surface arranged roughly in circular groups. In one specimen a narrow umbilical canal was seen.

* This movement has been observed by Allman (1872) and Murbach (1899), but was not seen by Hargitt (1904) or Brückner (1914). Among the many medusæ that we have seen, however, we have only occasionally observed it. 
Great difficulty was experienced in getting the medusæ to grow ; the largest specimens reached a height of $1.4 \mathrm{~mm}$. They were females with few eggs, generally 1 to 3 in each interradius. In some the stomach

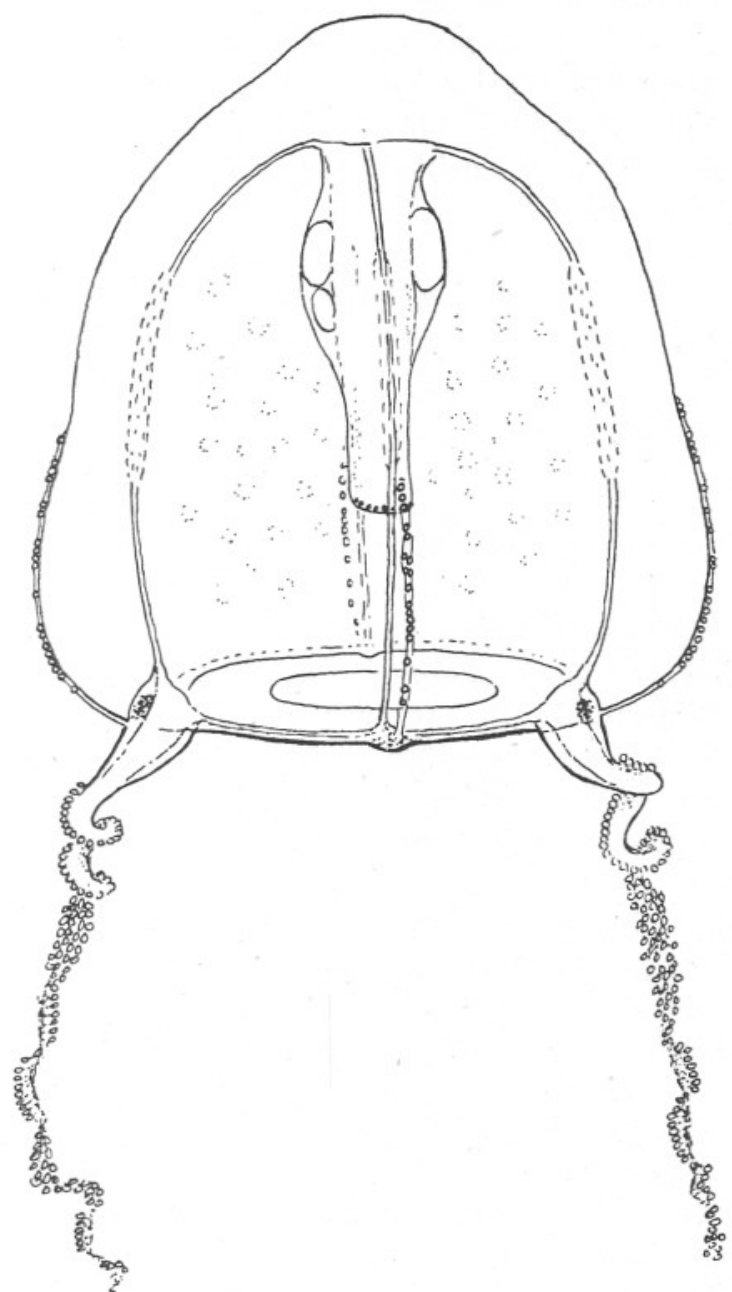

FIG. 12.-Mature medusa, Zanclea gemmosa, reared from the hydroid Zanclea implexa, $1.4 \mathrm{~mm}$. in height; Plymouth, 30.v.36. The tentacles have been cut short in the drawing, and should have $c a .300$ nematocyst capsules each. The nematocysts in the tentacle bulbs are not shown. Del.F.S.R.

extended nearly to the margin of the umbrella. In some the jelly of the umbrella had become thickened at its apex and in the four radii in the region of the exumbrella nematocyst channels. The shape of the exumbrella nematocyst chambers had altered, and they now had no sac-like 
dilatations, but extended upwards as linear channels for more than a third, or even than a half, of the exumbrella surface ; they contained 16 to 20 nematocysts, mostly in a single row, with occasionally two side by side. There was no indication of any increase in size of the non-tentacular bulbs. The number of stalked capsules on each tentacle had greatly increased to approximately 300 and they measured $0.022 \mathrm{~mm}$. in length by 0.015 in breadth. There were distinct linear swellings along the middle portions of each radial canal, and the pattern of fine dotted circles on the umbrella was quite obvious (Fig. 12).

\section{Discussion.}

The historical literature on the synonymy of the species of Zanclea and Gemmaria is long and involved. The salient points on which differences arise appear to be as follows.

\section{The Hydroid.}

1. The European species of Zanclea has a well developed, sometimes annulated, perisare on the hydrocaulus, as well as a perisare on the hydrorhiza, cf., Zanclea implexa of British waters, Gemmaria implexa at Naples $($ Hargitt, 1904)=Z. Hargitti $($ Hartlaub, 1907) $=Z$. implexa var. neapolitana (Brückner, 1914). Also in ? Gemmaria costata from Tortugas (Mayer, 1910=Gemmaria gemmosa of Mayer, 1900).

The American species of Gemmaria has no visible perisare on the hydrocaulus or hydrorhiza, cf., Halocharis spiralis (Agassiz, 1862), Corynitis agassizii* (Murbach, 1899).

2. Medusa buds are borne in the proximal region of the tentacles (Allman, 1872, Gemmaria implexa). Medusa buds are " most numerous in a zone where the rudimentary tentacles are, though scattered ones may also be found higher up the polyp." (Murbach, 1899, Corynitis agassizii.)

Medusa buds are borne scattered amongst the tentacles " at any point or portion of the hydranth, and quite as frequently near the oral as the basal region of the body" (Hargitt, 1904, Gemmaria implexa; and also Brückner, 1914, Z. implexa var. neapolitana). Medusa buds are borne below the tentacles (Mayer, 1910, ? Gemmaria costata).

3. The perisarc of the hydrocaulus in European species has an investing outer sheath or " periderm " (Alder, 1857); this was not seen by Allman (1872), but Brückner (1914) has shown the presence of a somewhat similar outer coat.

The Medusa.

1. The nematocyst armature on the exumbrella is present as tracks (nessel rippen) in adults (Gegenbaur, 1856, Zanclea costata ; Browne, 1905,

\footnotetext{
* For a criticism of this erroneous name see Hargitt (1908).
} 
Gemmaria implexa; Bigelow, 1909, Zanclea gemmosa; Mayer, 1910, Pl. 8, Fig. 6, ? Zanclea costata.)

The nematocyst armature on the exumbrella is present as channels ending in blind sacs (nesselpolstern) in young stages (McCrady, 1856, Zanclea gemmosa; Allman, 1872, Gemmaria implexa ; Murbach, 1899, from Corynitis agassizii ; Mayer, 1900 and 1910, ? Zanclea costata, Pl. 8, Fig. 3, and Zanclea gemmosa ; Brückner, 1914, Z. implexa var. neapolitana). On these grounds Brückner separates the genera Zanclea and Gemmaria.

2. All known young stages liberated from the hydroid have only two tentacles. Adults with two tentacles have also commonly been recorded from the plankton. Medusæ with four tentacles (as in Gegenbaur's original Zanclea costata) may be taken in the plankton.

3. In almost all recorded specimens the mouth has no lips, but the presence of four short lips is given by Gegenbaur in his original description of Zanclea costata.

4. The jelly may be thin (e.g. Neppi and Stiasny, 1913), or it may be recorded as having a thickened apical process (e.g. Browne, 1905, and Hartlaub, 1907, Fig. 111).

5. There may be a peduncle above the stomach (e.g. Browne, 1905; Hartlaub, 1907, Fig. 111).

6. The stalked capsules on the tentacles are sagittate (McCrady, 1857), spherical (Mayer, 1910, Pl. 8, Fig. 7, and Vanhöffen, 1911, p. 200, Fig. 3), but in all other descriptions oval.

Let us now consider these points individually.

\section{The Hydroid.}

1. The presence or absence of perisare has been regarded by several authors as a generic character (e.g., Hartlaub, 1907, Zanclea and Halocharis; and Stechow, 1923). We have now shown that the perisare of the hydrocaulus and hydrorhiza is only developed with age, and is therefore not necessarily a distinguishing character between the European and American species. As regards the American hydroid Murbach (1899) incidentally adds the following footnote: "This summer I have found what appears to be a second species of Corynitis. It differs from $C$. agassizii in the presence of a well-developed perisare on the hydrorhiza and the short hydrocaulus, forming imperfectly annulated cups about one fourth the length of the polyp, and in the fact that the medusa-buds are on branched stalks." This may well have been an older colony than he had seen before.

2. We have shown that the method of production of medusa buds is an extremely variable character.

3. The presence of an outer periderm over the hydrocaulus observed by Alder, was not seen by Allman. Strethill Wright (1859, p. 108) comments 
as follows: "The internal layer of the corallum is brown and of horny texture; the external coat colourless and membranous. The first is frequently annulated; the second not so, but is occasionally gathered in longitudinal folds. I am disposed to think that this coat is the 'colletoderm,' or glutinous covering of the corallum (in this species highly developed and indurated), separated from the inner coat by the action of the spirit in which the specimen was immersed." Brückner (1914) says of the Naples variety that the hydrocaulus is always simple in its whole course, but occasionally the double walled protective covering is produced by a slimy gelatinous mass over the periderm which becomes separated from it as a thin layer. He would not decide whether this formation could be regarded as identical with that described by Alder. A kind of douk" was observed by Stechow* (1925, p. 23), from material " nach pei England" from the Valdivia Expedition. We have explained on page 112 how this appearance is produced with age (see also Hincks, 1872, p. 394). Altogether this character appears to be rather inconstant and of very doubtful specific value.

\section{The Medusa.}

1. We have shown that the "nesselpolstern" develop into "nesselrippen." McCrady (1857) in his original description of the genus Zanclea says : "The thread-cells in the older animals are arranged one by one along the row, but in the younger there is simply a cluster of them above each tentaculum." As regards Z. gemmosa he also says: "Their disposition in a cluster is probably a character of very young individuals, for I have found a specimen not differing much in size from the rest which had these cells arranged in a row one by one as in Gegenbaur's species."

The fact that Graeffe (1884) says that in the Mediterranean the medusa makes no metamorphosis cannot be regarded seriously in this respect as it is doubtful whether at that date he would have studied this particular point.

2. Browne (1905) † remarking on the presence of medusæ with two and four tentacles in the plankton at the same time says: "I do not think that they are distinct species, as they are similar in every detail except in the number of tentacles." This opinion was also held by Mayer (1910).

We have seen a Zanclea with four tentacles from the plankton at Plymouth (F. S. R., 19. vii. 34) which was almost the same size as the largest medusa with two tentacles that we have reared. The fact that all four tentacles were equally developed rather suggests that it was liberated from its hydroid with the four tentacles already formed. On

\footnotetext{
* It was recorded as not seen by Stechow (1919, p. 5), but in this (1925) report he says that the species was not $G$. implexa, but rather Sarsia pulchella (Allman).

$\dagger$ The only other British records not cited are Browne (1896), Browne and Vallentin (1904), Delap, M. and C. (1905) and Robson (1914).
} 
the whole, therefore, no certain opinion can be expressed on this point until a medusa with four tentacles has been reared from a hydroid.

3. Although Gegenbaur (1856) in his original description of $Z$. costata says that the mouth has four short lips his drawing leads one to suppose that they are so slightly developed that they could hardly be termed "lips." It is possible that in large individuals the mouth corners tend to develop slightly to give this appearance. Mayer (1910) says: "The common Zanclea of the southern coast of New England, in America, may become mature with only 2 tentacles, and with poorly developed lips. On the other hand, a very similar medusa is occasionally found in the same waters with 4 tentacles and with 4 well-developed lips. I am inclined to brlleve that these conditions represent developmental stages, or starved and well-fed states of one and the same medusa."

4. We have shown that the thickness of the jelly can increase with age; this can hardly be a character of specific value.

5. Hartlaub (1907) says that the Trieste form differs from the British form in the absence of a stomach peduncle, and Neppi and Stiasny (1913) confirm this for the Mediterranean. Browne (1905) also records that the stomach is upon a short peduncle. It is doubtful to what extent this peduncle is any more than a reflection of the thickness of the apical jelly.

6. Although McCrady (1857) drew the stalked capsules of the young American medusæ with points (Agassiz, 1865, refers to them as " arrowshaped "), Murbach drew them as ovals. There seems to be no doubt that such differences may be due entirely to inaccurate draughtsmanship. Our capsules agreed closely in outline with those drawn by Murbach (1899) and Brückner (1914). Vanhöffen (1911) divided the Zanclea species from the Valdivia Expedition into two series in which the nematocyst capsules were small spherical, and large oval, their measurements being $0.02 \mathrm{~mm}$. diameter and $0.05-0.06 \mathrm{~mm}$. long respectively. On the grounds that those with small capsules had long exumbrellar nematocyst canals, he regarded them as Zanclea costata Gegenbaur although they had but two tentacles (cf. also Mayer, 1910, Pl. 8, Fig. 7). Those with large capsules had short "Nesselpolster" and were regarded as being Zanclea implexa (Alder). As regards size of capsules our specimens agree with Vanhöffen's first group, although in shape they come into his second group. But the possibility that the spherical appearance may be due to contraction in the preserved state must be borne in mind. In some of our specimens on preservation the capsules appeared distinctly spherical.

A consideration of the above points leads to the conclusion that no character can be brought forward whereby the Zanclea implexa of the European coasts and Gemmaria gemmosa of the American coasts can be regarded as specifically distinct. On these grounds it seems only right that the two should be united, with perhaps the proviso that in the young 
medusæ of the American form the perradial nematocyst pads are usually short. In doing this it will be necessary to take the name Zanclea implexa (Alder) as having priority for the hydroid and Zanclea gemmosa McCrady for the medusa. This is assuming for the moment that the four-tentacled medusa is kept distinct as Zanclea costata Gegenbaur. If it should be found that at times Zanclea implexa produces a medusa which already has four tentacles or develops them later, then the name Z. gemmosa will have to give way to $Z$. costata Gegenbaur.

It would appear that Zanclea gemmosa is a medusa with a world-wide distribution. Bigelow (1909) recorded it from Acapulco Harbour in the Pacific, noting that the exumbrella nematocyst channels were rather longer than in McCrady's medusa. Uchida (1927) has recorded a Zanclea from Japan which " is perhaps referable to Z. gemmosa," . . . " but is distinguished by its smaller size, ellipsoidal shape, thick jelly and different coloration." None of these characters can be regarded as having specific value. Weill (1934, p. 422) has also recorded Gemmaria gemmosa from the Gulf of Siam.

The hydroid Gemmaria gemmosa has been recorded by Stechow (1911) from the coast of Japan; this was referred by him later (Stechow, 1923, b) to the genus Halocharis.

Of other records of Zanclea (or probable Zanclea) hydroids there are Coryne sessitis Gosse (1853, p. 208, Pl. XIV, Figs. 1-3) found in a rock pool at Capstone on the north Devon coast " from a crust of Lepralia . . . , close around the base of a cluster of Cellularia avicularia" ; Gymnocoryne coronata Hincks (1871, p. 75, Pl. V, Fig. 1) from Salcombe, South Devon; Coryne vel Syncoryne cylindrica Kirkpatrick (1890, p. 605, Pl. XIV, Fig. 1), from Albany Passage, N. Queensland, growing with Cellepora granulosa; Gemmaria nitida Hartlaub (1905, p. 527) from Juan Fernandez; and Zanclea protecta Hastings (1930 and 1932) from the Tropical East Pacific and the Great Barrier Reef of Australia in association with various polyzoa.

Of these Coryne sessitis Gosse differs somewhat from our Zanclea in having all the tentacles arranged in whorls. Albeit his drawing shows an extraordinarily close resemblance with that by Mayer (1900) of a hydroid from which he obtained the Gemmaria gemmosa medusæ which he later (1910) thought might be $Z$. costata. Gymnocoryne coronata Hincks is almost certainly a young Zanclea in which the perisarc is not yet developed on the hydrocaulus; it differs from our Zanclea in having 8 or 9 tentacles in the apical whorl. It is doubtful whether this is a specific difference. Syncoryne cylindrica Kirkpatrick only differs from Zanclea protecta Hastings in the weaker development of perisarc. For $Z$. protecta Hastings (1930) gives the differences from other known species as " smaller number of shorter, relatively thicker tentacles, the very slight development of the perisarc, and in the gonophores, which originate directly 
from the hydrorhiza-not from the hydranth." The first two of these characters cannot be regarded as specific in the light of our observations, while the description of the stalks with medusa buds shows a very suggestive similarity with our blastostyles.

Hastings, however (1932), has shown that there is a difference in the nematocyst armatures of $C$. cylindrica and $Z$. protecta. While $Z$. protecta had only one kind of nematocyst, $0.009 \mathrm{~mm}$. in length by $0.007 \mathrm{~mm}$. in width (Hastings, 1930), C. cylindrica had also large nematocysts $0.032 \mathrm{~mm}$. by $0.016 \mathrm{~mm}$. We have shown (p. 111) that $Z$. implexa has the three types of nematocysts observed by Brückner (1914).

Hartlaub's Gemmaria nitida shows no specific characters to distinguish it from $Z$. implexa, but the absence of fully developed medusa buds does not allow a final opinion.

At this stage, therefore, we cannot combine all the species of Zanclea hydroids as the great difficulty of distinguishing other hydroids which produce different species of medusæ is well-known. Until the true story of the Zanclea species of medusæ is known we can go no further.

Of the medusæ other than the two tentacled Zanclea gemmosa McCrady and the four tentacled Zanclea costata Gegenbaur, there remain only Gemmaria cladophora Agassiz (1865), Gemmaria sagittaria Haeckel (1879), and Zanclea orientalis Browne (1916). As regards G. cladophora the character of the shape of the subumbrella cavity hardly seems to be specific. The unequal development of the tentacles is however interesting as being possibly an intermediate stage between the two tentacled and four tentacled medusæ. On the whole this must remain a doubtful species as must $G$. sagittaria. Zanclea orientalis, from the Chagos Archipelago in the Indian Ocean, has the distinguishing character of broad perradial patches of nematocysts on the umbrella margin, and until it can be shown whether this is a permanent character or not it must be kept as a distinct species. Albeit the other three uncertain specimens of Zanclea which Browne records from the Indian Ocean appear to be closely similar to Zanclea gemmosa *

Two other species of Zanclea are recorded in the literature namely, Zanclea dichotoma Mayer (1900) and Zanclea maasi Uchida; these have been removed to the separate genera Zancleopsis (Hartlaub, 1907) and Urashimea (Uchida, 1927) respectively. Weill (1934) has reviewed the systematic position of Zanclea at some length. He has laid stress on whether the nematocyst canals are exumbrellar (" cnidacts " of Günther, 1903) or "endo-ombrellaire" ; he gives the name of " cnidothylacies " to the latter. It seems that he has regarded Allman's description (1859) " in the substance of the umbrella " too literally, although Allman states that

* It should be noted that Browne mentions that in one of these the nematocyst capsules on the tentacles were about twice the size of those of $Z$. orientalis (cf. Vanhöffen, 1911). 
these are "close upon its outer surface." We are unable to agree with Weill's conclusion that Zanclea implexa should be placed in his new genus Güntherella.

It is suggested that the synonymy of the hydroid and medusa of Zanclea implexa now becomes:

Hydroid. Zanclea implexa (Alder).

? Coryne sessitis, * Gosse (1853).

Tubularia implexa, Alder (1857).

Coryne pelagica, Alder (1857).

Coryne briareus, Allman (1859).

Coryne margarica, Strethill Wright (1859).

- Coryne implexa, Strethill Wright (1859).

Halocharis spiralis, Agassiz (1862).

Zanclea implexa, Allman (1864).

Gymnocoryne coronata, Hincks (1871).

Gemmaria implexa, Allman (1872).

"Corynitis agassizii," Murbach (1899).

? Gemmaria gemmosa, Mayer (1900).

Zanclea hargitti, Hartlaub (1907).

? Gemmaria costata, Mayer (1910).

Gemmaria gemmosa, Stechow (1911).

Zanclea implexa var. neapolitana, Brückner (1914).

Halocharis gemmosa, Stechow $(1923$, b).

Medusa. Zanclea gemmosa McCrady (1857).

Coryne implexa, Alder (1862).

Zanclea implexa, Allman (1864).

Gemmaria gemmosa, Agassiz (1865).

Gemmaria implexa, Allman (1872).

" Corynitis agassizii," Hargitt (1905).

? Zanclea costata (Mayer, 1910 ; Vanhöffen, 1911).

Güntherella implexa, Weill (1934).

\section{SUMMARY.}

A colony of the hydroid Zanclea implexa (Alder) has been grown in the laboratory from the first appearance of the polyps until the colony was six months old. A second colony brought into the laboratory in a later stage of development has also been kept alive for six months. Both colonies were growing in association with polyzoa, the second being with Cellepora avicularis Hincks. In the earliest stages of development no

* If future research should show that the Coryne sessilis of Gosse is to be regarded as synonymous with Zanclea implexa (Alder) then the name Zanclea implexa will have to be replaced by Zanclea sessilis (Gosse). 
perisarc was visible on the hydrocaulus. Medusa bud formation was followed, and some medusæ reared to the adult stage.

A consideration of the changes undergone by the hydroid and medusa during their course of development indicates the necessity of uniting Zanclea implexa of the European coasts with Gemmaria gemmosa of the American coasts. On the grounds of priority the name for the hydroid must be Zanclea implexa (Alder) and that for the medusa Zanclea gemmosa McCrady. The medusa with four tentacles, Zanclea costata Gegenbaur, is provisionally kept as a separate species.

The genus Zanclea is reviewed, and as complete a bibliography as possible has been appended.

\section{BIBLIOGRAPHY.}

It is hoped that this is a complete list of all known literature in which Zanclea is recorded.

Agassiz, Louis. 1862. Contributions to the Natural History of the United States of America, Vol. IV, pp. 1-380.

Agassiz, Alexander. 1865. Illustrated Catalogue of the Museum of Comparative Zoölogy at Harvard College. No. II, North American Acalephæ, pp. 1-234.

Alder, Joshua. 1857. A Catalogue of the Zoophytes of Northumberland and Durham. Trans. Tyneside Naturalists' Field Club, Vol. III, pp. 93-162.

- 1862. Supplement to a Catalogue of the Zoophytes of Northumberland and Durham. Trans. Tyneside Nat. Field Club, Vol. V, Pt. III, pp. 225-247.

Allman, G. J. 1859. Notes on the Hydroid Zoophytes. Ann. Mag. Nat. Hist., Ser. 3, Vol. 4, pp. 48-55; and pp. 137-144.

- 1864. On the Construction and Limitation of Genera among the Hydroida. Ann. Mag. Nat. Hist., Ser. 3, Vol. 13, pp. 345-380.

— 1864. Notes on the Hydroida. Ibid., Vol. 14, pp. 57-64.

Allman, George James. 1871-72. A Monograph of the Gynmoblastic or Tubularian Hydroids, pp. 1-450.

Allman, G. J. 1888. Report on the Hydroida dredged by H. M. S. Challenger during the years 1873-76. Pt. 2. The Tubularinæ, Corymorphinæ, Campanulinæ, Sertularinæ, and Thalmophora. Rep. Sci. Res. Voy. Challenger (Zool.), Vol. 23, LXIX, 90 pp.

Bigelow, Henry B. 1909. Rep. Sci. Res. Exped. Eastern Tropical Pacific ..." Albatross." XVI. The Medusæ. Mem. Mus. Comp. Zoöl. Harvard, Vol. XXXVII, pp. 1-243. 
Bigelow, Henry B. 1914. Fauna of New England. 12. List of the Medusæ Craspedotæ, Siphonophoræ, Scyphomedusæ, Ctenophoræ Occ. Papers Boston Soc. Nat. Hist., Vol. VII, pp. 1-37.

Bonnevie, Kr. 1901. Meeresfauna von Bergen, Heft. I, pp. 1-15. Bergens Museum.

Brooks, W. K. 1882. List of Medusæ found at Beaufort N.C. during the summers of 1880 and 1881. Johns Hopkins Univ. Studies from Biol. Lab., Vol. 2 (No. 2), pp. 135-146.

Browne, Edward T. 1896. On British Hydroids and Medusæ. Proc. Zool. Soc. London, pp. 459-500.

1898. On the Pelagic Fauna of Plymouth for September, 1897. Journ. Mar. Biol. Assoc., N.S., Vol. V, No. 2, pp. 186-192.

— 1905. A Report on the Medusæ found in the Firth of Clyde (19011902). Proc. Roy. Soc. Edinburgh, Vol. XXV, Pt. IX, pp. 738-778.

— 1910. Cœlentera. V. Medusæ. National Antarctic Exped. 19011904. Nat. Hist., Vol. V, pp. 1-62.

1916. Medusæ from the Indian Ocean. Trans. Linn. Soc. London, 2nd Ser. Zool., Vol. XVII, Pt. 2, pp. 169-2ī0.

Browne, E. T. and Vallentin, R. 1904. On the Marine Fauna of the Isles of Scilly. Journ. R. Instit. Cornwall, Vol. 50, pp. 120-132.

Brǘckner, ErICH. 1914. Beitrag zur Kenntnis von Perigonimus cidaritis Weismann und Gemmaria implexa var. neapolitana Hargitt. Z. wiss. Zool. Leipzig, Bd. CXI, pp. 445-505.

Delap, M. and Delap, C. 1905. Notes on the Plankton of Valencia Harbour. Fisheries, Ireland, Sci. Invest., No. VII, pp. 3-21.

Du Plessis, G. 1881. Catalogue provisoire des Hydroïdes médusipares (Hydroméduses vraies) observés durant l'hiver 1879-80 à la Station zoologique de Naples. Mitt. Zool. Stat. Neapel, Bd. II, pp. 143-149.

Fewkes, J. Walter. 1881. Studies of the Jelly-fishes of Marragausett Bay. Bull. Mus. comp. Zoöl. Harvard, Vol. VIII, No. 8, pp. 141-182.

Gegenbaur, Carl. 1856. Versuch eines Systemes der Medusen, mit Beschreibung neuer oder wenig gekannter Formen; zugleich ein Beitrag zur Kenntniss der Fauna des Mittelmeeres. Z. wiss. Zool. Leipzig, Bd. VIII, pp. 202-273.

Gosse, Philip Henry. 1853. A Naturalist's Rambles on the Devonshire Coast. London, John van Voorst, pp. 1-448. 
Graeffe, Ed. 1884. Uebersicht der Seethierfauna des Golfes von Triest nebst Notizen über Vorkommen, Lebens-weise, Erscheinungs- und Fort-pflanzungs-zeit der einzelnen Arten. Arb. Zool. Inst. Univ. Wien u. Zool. Stat. Triest, Tom. V, Heft. 3, pp. 333-362.

Günther, R. T. 1903. On the Structure and Affinities of Mnestra parasites Krohn; with a revision of the classification of the Cladonemidæ. Mitt. Zool. Stat. Neapel., Bd. 16 (1903-1904), Heft I and II, pp. 35-62.

Haeckel, Ernst. 1879. Das System der Medusen.

Hargitt, Chas. W. 1904. Notes on some Hydromedusæ from the Bay of Naples. Mitt. Zool. Stat. Neapel, Bd. 16 (1903-1904), Heft. 4, pp. 553-585.

1905. The Medusæ of the Woods Hole Region. Bull. Bur. Fish. Washington, Vol. XXIV (1904), pp. 23-79.

1908. Notes on a few Cœlenterates of Woods Holl. Biol. Bull. Woods Hole, Vol. XIV, No. 2, pp. 95-120.

Hartlaub, Clemens. 1887. Zur Kenntnis der Cladonemiden. Zool. Anz. Leipzig, X Jahrg., II. Wiss. Mitth., 3, pp. 651-658.

Hartlaub, Cl. 1905. Die Hydroiden der magelhaensischen Region und Chilensis Küste. Zool. Jahrb. System. Suppl. VI (Fauna Chilensis III, Heft. 3, pp. 497-714).

— 1907. Nordisches Plankton. Lief. 6. XII. Craspedote Medusen. Teil 1. Lief. 1. Codoniden und Cladonemiden, pp. 1-135.

— 1917. Nordisches Plankton. Lief. 19. XII.- Craspedote Medusen. Teil 1. Lief. 4, pp. 365-479.

Hastings, Anna B. 1930. On the Association of a Gymnoblastic Hydroid (Zanclea protecta, sp. n.) with various Cheilostomatous Polyzoa from the Tropical E. Pacific. Ann. Mag. Nat. Hist. Ser. 10. Vol. V, pp. 552-560.

1932. The Polyzoa, with a note on an Associated Hydroid. Great Barrier Reef Exped. 1928-29. Sci. Rep. (Brit. Mus.), Vol. IV, No. 12, pp. 399-458.

Hincks, Thomas. 1868. A History of the British Hydroid Zoophytes Vols. I-II.

— 1871. Supplement to a "Catalogue of the Zoophytes of South Devon and South Cornwall," with Descriptions of new species. Ann. Mag. Nat. Hist, Vol. VIII (4th Ser.), No. 44, IX, pp. 73-83. 
Hincks, Thomas. 1872. Contributions to the History of the Hydroida. Ann. Mag. Nat. Hist., Vol. X (4th Ser.), No. 59, LIV, pp. 385-395.

Jickeli, C. F. 1883. Der Bau der Hydroidpolypen. Morph. Jahrb. Bd. 8, pp. 373-416 and 580-680.

KiRkpatrick, R. 1890. Reports on the Zoological collections made in Torres Straits by Professor A. C. Haddon, 1888-1889. Hydroida and Polyzoa. Sci. Proc. roy. Dublin Soc., Vol. VI, Pt. X, pp. 603-626.

Leslie, G. and Herdman, W. A. 1881. The Invertebrate fauna of the Firth of Forth. 106 pp. Edinburgh.

Lo Bianco, Salvatore. 1909. Notizie biologiche riguardanti specialmente il periodo di maturità sessuale degli animali del Golfo di Napoli. Mitt. Zool. Stat. Neapel, Bd. XIX, Heft. 4, pp. 513-761.

Marine Biological Assoctation. 1931. Plymouth Marine Fauna. Second Edition.

Mayer, Alfred Goldsborough. 1900. Some Medusæ from the Tortugas, Florida. Bull. Mus. Comp. Zoöl. Harvard, Vol. XXXVII, No. 2, pp. 13-82.

\section{— 1910. Medusæ of the World. Vol. I. Hydromedusæ.}

McCrady, John. 1857. Gymnophthalmata of Charleston Harbour. Proc. Elliott Soc. Nat. Hist. Charleston, South-Carolina, Vol. I, 1859 (Nov. 1853-Dec. 1858), pp. 103-294.

Motz-Kossowska, S. 1905. Contribution à la Connaissance des Hydraires de la Méditerranée occidentale. I.-Hydraires Gymnoblastiques. Arch. Zool. Expér. Gén., Ser. 4, Tome III, pp. 39-98.

Murbach, L. 1899. Hydroids from Wood's Holl. Mass. Hippolytus peregrinus, a new unattached Marine Hydroid: Corynitis Agassizii and its medusa. Quart. J. Micr. Sci., London, Vol. 42, Pt. 3, N.S., pp. 341-360.

Neppi, Valeria. 1920. Nuove osservazioni sui polipi idroidi del Golfo di Napoli. Pubb. Stat. Zool., Napoli, Vol. 3 (1921), pp. 1-31.

Neppi, Valeria and Stiasny, Gustav. 1913. Die Hydromedusen des Golfes von Triest. Arb. Zool. Inst. Univ. Wien u. Zool. Stat. Triest, Bd. XX, pp. 23-90.

Nutring, C. C. 1901. The Hydroids of the Woods Hole Region. Bull. U. S. Fish Comm., Washington, Vol. XIX (1899), pp. 325-386.

Pennington, Arthur. S. 1885. British Zoophytes: An Introduction to the Hydroida, Actinozoa and Polyzoa found in Great Britain, Ireland, and the Channel Islands, $363 \mathrm{pp}$. London. 
RANkin, James. 1901. Hydroida, p. 369 in Fauna, Flora, and Geology of the Clyde Area, Glasgow.

Robson, J. H. 1914. Catalogue of the Hydrozoa of the North-east Coast (Northumberland and Durham). Dove Marine Laboratory Report for the year ending June, 1914, pp. 87-103.

Schneider, K. C. 1890. Histologie von Hydra fusca mit besonderer Berücksichtigung des Nerven Systems der Hydropolypen. Arch. Mikrosk. Anat., Bd. 35, pp. 321-379.

- 1898. Hydropolypen von Rovigno, nebst Übersicht über das System der Hydropolypen im Allgemeinen. Zool. Jahrb. (Syst.), Bd. X, pp. 472-555.

Stechow, E. 1911. Hydroidpolypen der Japanischen Ostkuste, I. Teil. Athecata und Plumularidæ. Abhandlungen Math.-Phys. Klasse K. Bayr. Akademie der Wissenschaften (Doflein Naturgeschichte Ostasiens), I. Suppl.-Band 6. Abhandlung, p. 1-111.

1919. Zur Kenntnis der Hydroidenfauna des Mittelmeeres, Amerikas und anderer Gebiete. Zool. Jahrb. Jena (Syst.), Bd. 42, pp. 1-172.

— 1923. Zur Kenntnis der Hydroidenfauna des Mittelmeeres, Amerikas und anderer Gebiete. Zool. Jahrb. Syst. Bd. 47, pp. 29-270.

—_ 1923, b. Die Hydroidenfauna der Japanischen Region. J. Coll. Sci., Tokyo. Imp. Univ., Vol. XLIV, Art. 8, pp. 1-23.

Stechow, Eberhard. 1925. Hydroiden der Deutschen Tiefsee-Expedition. Wiss. Ergebn. Deutschen Tiefsee-Expedition Valdivia 18981899, Bd. XVII, Heft 3, pp. 387-546.

Swenander, Gust. 1904. Über die Athecaten Hydroiden des Drontheimsfjordes. K. norske Vidensk. Selsk. Trondheim. 1903. No. 6, pp. 3-18.

UChida, Tohru. 1927. Studies on Japanese Hydromedusæ. 1. Anthomedusæ. J. Fac. Sci. Univ. Tokyo, Zool., Vol. I, Pt. 3, pp. 145-241.

VANHöFfEn, ERNst. 1891. Versuch einer natürlichen Gruppierung der Anthomedusen. Zool. Anz. Leipzig, XIV Jahrg., I Wiss. Mitth., pp. $439-446$.

—_ 1911. Die Authomedusen und Leptomedusen der Deutschen Tiefsee-Expedition 1898-1899. Wiss. Ergeb. Deutschen TiefseeExped. Valdivia, Bd. XIX, 1925, Heft. 5, pp. 193-233.

Weill, Robert. 1934. Contribution à l'étude des Cnidaires et de leur Nématocystes. II. Valeur taxonomique du Cnidome. Trav. Stat. Zool. Wimereux, Tome XI, pp. 349-701. 
Wright, T. Strethill. 1859. Observations on British Zoophytes. Edinb. New Philos. Journ., N.S., Vol. 10, pp. 105-114.

Zoja, Raffaeiso. 1895. Sullo sviluppo dei blastomeri isolati dalle uova di alcune meduse (e di altri organismi). Arch. Entw. Org. Bd. II, Heft 1, pp. 1-37, Pl. IV, Figs. 121-123.

\section{ADDENDUM.}

Since passing the final proofs we have seen a report on the Hydroids of the Philippine Islands by Charles W. Hargitt (1924, Philipp. Journ. Sci., Vol. 24, No. 4, pp. 467-505). A new genus and species of hydroid is described, Zancloidea philippina. The hydroid differs from Zanclea in possessing filiform as well as capitate tentacles and the medusa in the absence of exumbrellar nematocyst channels. Hargitt mentions a medusa designated as Zanclea implexa by Neppi (Adriatische Hydromedusen, Kais. Akad. Wiss. Wien, Vol. 121, 1912, p. 11) which had four tentacles, abaxial purple-red ocelli on the tentacle bulbs, and lacked exumbrellar nematocyst channels. We have ourselves not seen this paper. 